\title{
Citizenship Norms in Eastern Europe
}

\author{
Hilde Coffé · Tanja van der Lippe
}

Accepted: 3 May 2009/Published online: 28 May 2009

(C) The Author(s) 2009. This article is published with open access at Springerlink.com

\begin{abstract}
Research on Eastern Europe stresses the weakness of its civil society and the lack of political and social involvement, neglecting the question: What do people themselves think it means to be a good citizen? This study looks at citizens' definitions of good citizenship in Poland, Slovenia, the Czech Republic and Hungary, using 2002 European Social Survey data. We investigate mean levels of civic mindedness in these countries and perform regression analyses to investigate whether factors traditionally associated with civic and political participation are also correlated with citizenship norms across Eastern Europe. We show that mean levels of civic mindedness differ significantly across the four Eastern European countries. We find some support for theories on civic and political participation when explaining norms of citizenship, but also demonstrate that individuallevel characteristics are differently related to citizenship norms across the countries of our study. Hence, our findings show that Eastern Europe is not a monolithic and homogeneous bloc, underscoring the importance of taking the specificities of countries into account.
\end{abstract}

Keywords Citizenship norms $\cdot$ Eastern Europe $\cdot$ Public opinion

What does it mean to be a citizen in Eastern Europe today? Most of the current research on citizenship in Eastern Europe is pervaded by concerns about low levels of organizational membership and political and electoral participation (Howard 2002): whatever eagerness there was to vote after democratization has apparently dissipated. However, what has largely been neglected in discussions on the lack of citizenship in Eastern Europe, is the citizens' own conceptualization of good citizenship. That is, what do citizens understand by the term "good citizenship"? These considerations about "good citizenship" might help

H. Coffé $(\bowtie)$

Department of Sociology/ICS, Utrecht University, Heidelberglaan 2, 3584 CS Utrecht,

The Netherlands

e-mail: h.r.coffe@uu.nl

T. van der Lippe

Utrecht University, Utrecht, The Netherlands 
us to understand why citizens behave in certain ways (van Deth 2007). Besides, the way citizens themselves define the concept of citizenship is a subject of crucial importance for policy makers, politicians and philosophers "who need to know what the present situation is before they can decide what should be done about it" (Conover et al. 1991: 801).

Even though political theorists have examined the qualities of good citizenship in depth, empirical political and social scientists have produced only a handful of studies-focusing on West European countries and the US-analyzing the public's understanding of this concept (Almond and Verba 1963; Conover et al. 2004; Dalton 2008a; Denters et al. 2007; Theiss-Morse 1993). In this paper, we look at which definitions of good citizenship are held by the citizens in four Eastern European countries: Poland, Hungary, the Czech Republic and Slovenia. In doing this, we hope to contribute to the scarce empirical studies on citizens' own perspectives, which have focused on Western countries. The Eastern European experience with communism makes their definitions of citizenship particularly interesting. In communism, citizens were not faced with choices (Colton 2000; Völker and Flap 2001); they were part of an act of mass mobilization demanded by a totalitarian regime that controlled most spheres of life and repressed all forms of autonomous non-state activity.

Our comparison of four Eastern European countries involves a comparative research strategy that contrasts a small number of cases in order to grasp the peculiarities of each case (Tilly 1984). While all four countries underwent a lengthy period of socialization to Soviet-style norms and behavior, and were characterized by similar state and party structures and economic and social mechanisms (McGregor 1996), there are broad contrasts between the countries. Indeed, even though each country was governed by a communist party for more than 40 years, the degree of penetration of communism in each country differs significantly. We will consider how these contextual differences within Eastern Europe may explain cross-national differences in citizenship norms.

Next to comparing the civic mindedness across four Eastern European countries, we investigate whether factors typically associated with civic participation-in mostly Western research-also influence civic mindedness. In other words, given the scarce empirical work on citizenship norms in general and in Eastern Europe in particular, we will test whether models of civic participation replicate to civic mindedness in recently established democracies. Besides, we explore whether these correlates operate in the same way in the four Eastern European countries involved in our study.

This article is structured as follows. We begin with a discussion on the effect of the historical and political context on citizenship norms. In the following section, we briefly review theories on civic and political participation which relevance for explaining citizenship norms will be tested in the empirical section. The next part introduces data and measurements. The analyses are presented in the third section. We conclude with a brief summary of the results and some suggestions for further research.

\section{Citizenship Norms Across Eastern European Countries}

Time and again, research on civic participation comparing Eastern and Western European countries has found lower levels of citizenship in Central European countries. For example, Fidrmuc and Gërxhani (2005), Curtis et al. (2001) and Howard (2002) show that Eastern European countries lag behind Western European countries with respect to civic participation. Similarly, Adam et al. (2004) and Paldam and Svedsen (2000) find a gap in the stock of social capital between Western countries and formerly communist countries and 
ascribe it to the legacy of communism. Looking at citizenship norms, Denters et al. (2007: 97), find prevalent differences between the east and the west. In traditional Western European countries, citizens give the highest priority to critical and deliberative principles of citizenship, followed by law-abidingness and solidarity. In Eastern nations, law-abidingness ranks first and critical and deliberative values second.

Lower levels of participation and citizenship among citizens in Eastern Europe are often blamed on the communist experience (Adam et al. 2004; Curtis et al. 2001; Howard 2002; Hutcheson and Korosteleva 2006; Inglehart and Catterberg 2002; Paldam and Svedsen 2000). According to Curtis et al. (2001: 787) "citizens of established and stable democracies, because they generally have had more experience with the principles and practices of free association, will tend to be more active in forming and joining voluntary organizations of different types". In a similar line of reasoning, Schwartz and Bardi (1997) state that the adjustments to life under communism have clear implications for values. We argue that this obviously applies to norms regarding democratic citizenship, the expression of which was frustrated during communism. Indeed, communism meant that the only choice of political identification was identification with the party-the Communist Party (Rose and Makkai 1995). The electorate could not choose between competing political parties and was more an object of politics then an active political subject (Wolchik 1992). In addition, communist regimes sought to repress all forms of autonomous non-state activity, and supplanted and subverted such activity by forcing their citizens to join and participate in mandatory, state-controlled organizations (Howard 2002). Hence, the new regimes that arose after the collapse of communism challenged people to re-learn political and civic attitudes and behavior (Mishler and Rose 2002).

Despite the clear demarcation that has been found between Western and Eastern European countries with respect to citizenship, significant differences between Eastern European countries also occur. For example, Curtis et al. (2001) show that whereas participation in associations is generally lower within Eastern European nations, East Germany ranks significantly higher than the average count for all nations. Likewise, Rose et al. (1998) have argued that there is fairly wide variation among the countries of the postcommunist region with respect to civil society. With respect to citizenship norms, Denters et al. (2007) also reveal significant outliers in their regional Eastern/Western pattern. For example, according to their findings, Slovenia joins the group of Western European democracies, rather than the group of Eastern nations. We argue that an obvious potential explanation for these differences across countries within Eastern Europe may be the contrasting ways in which communism was experienced within the Eastern European countries. There were differences in the way communism was introduced and citizens were repressed, and also in the way the communist regime fell and the process of democratization was experienced, which may result in different norms for civic-oriented behavior. Indeed, Schwartz and Bardi (1997) argue that the impact of communism on values and norms is weaker where the resistance and opposition to communism were greater. Based on this, we would expect to find more civic mindedness in countries with a weaker penetration of communism; therefore, we expect to find fewer civic norms in a country like the Czech Republic, which was characterized by a "hard line" and very rigid communism after 1968 (Wallace 1997). Janos (1996) describes Czechoslovakia after 1968 as an étatist, militarized, solidary state, whereas he labeled Hungary, Poland and Yugoslavia as reformist (market socialist), civic states. The political formula that existed in Czechoslovakia identified the fundamental purpose of the state as promoting proletarian internationalism and operational codes, reflected in both public policy and the cultural norms fostered by the party leadership. Mishler and Rose (2002: 10) indicate that months before 
the fall of the Berlin wall, Freedom House classified Poland, Hungary and Yugoslavia as "partly free," whereas Czechoslovakia was placed almost at the extreme undemocratic endpoint.

As Ishiyama (1995: 158) notes, the Czech communist party had "a long tradition as a 'home-grown' communist movement, although this image was seriously tarnished by the events of 1968." In contrast, the Polish United Workers Party (PUWP) and the Hungarian Socialist Workers' Party were perceived as an "alien" political force, imposed from the outside by the Soviet Union (Ishiyama 1995). Ishiyama (1995: 158-159) goes on to state that "the lack of domestic legitimacy resulted in a greater willingness on the part of the Polish and Hungarian parties to engage in economic and political reform to 'legitimize' party rule, as compared to the Czechoslovak communist party." In the Polish and Hungarian communist parties, there also emerged a historical tradition of tolerance for some measure of intra-party political pluralism and moderate reform, which implied a greater willingness to accept the movement toward democratic reform (Ishiyama 1995).

In contrast, the Czech communist party tended to produce ideological conformity. At the end of the 1980s-when communism crumbled in Eastern Europe-the Czech elite, in contrast to their Polish and Hungarian counterparts, initially appeared confident and were willing to employ force in order to maintain communist rules (Völgyes 1992). The Czech leadership — which had little experience with reform or societal negotiation, given the stagnation of the Czech communist party after 1968 (Grzymala-Busse 2002) - put little effort into reaching any sort of accommodation with the opposition prior to the end of communist rule, as occurred in Hungary and Poland (Wolchik 1992).

In Poland, the communist military regime of the 1980s undertook significant economic reforms and emerged as an engine of market liberalization (Markowski 1997). In other words, there was greater willingness among the forces of the old regime in Poland to make concessions and promote change. A survey of local leaders conducted in Poland in the fall/ winter of 1989/1990 revealed an unexpectedly high degree of acceptance of democratic change (Wiatr 2003). Moreover, Poland was blessed with an individual (Lech Walesa) and an organization (Solidarnos' ${ }^{\prime}$ [Solidarity]) that became the focus of change. It has indeed been argued that the importance of the Solidarity movement, which enjoyed support from the majority of Polish citizens, cannot be overestimated (Bakuniak and Nowak 1987; Raciborski and Wiatr 2005). Solidarity embodied a collective actor that undertook action on the scale of the entire society. Besides, the Polish communist state failed in its attempt to prevent the public presence and even the functioning of the churches (Tomka 1998). The Polish church played a significant role in safeguarding the national consciousness and was closely connected with anti-communist resistance (Schanda 2003). It became a focal point for dissent in the 1980s and was the bastion of independence from communist control (Korbonski 1992; Need and Evans 2001; Rose-Ackerman 2001).

In Hungary, the attack on communism as a system first came from among the ranks of communist reformers themselves. They had already promoted a "goulash socialism" during the communist period: a set of measures intended to raise living standards while maintaining state control (Rose and Makkai 1995).

Slovenia (due mainly to a favorable initial economic position and pre-existing social policies) was able to absorb economic shocks and managed to experience a "soft transition" (Wright et al. 2004). The composition of Slovenia's economic structure is also closest to that of West European states, and there has been less continuity of the postcommunist state and administrative legacies in the country. Moreover, Slovenia has had the lowest level of welfare problems (Dyson 2007). 


\section{Individual Sources of Civic and Political Participation}

Political theorists have discussed about good citizenship for centuries and even today, citizenship is a highly contested concept. Civic virtues such as moral obligation to pursue the common good, social engagement, and political activism have been interpreted as prerequisites of good citizenship (Denters et al. 2007). However, whether or not all citizens are willing to take on such responsibilities is a matter of debate and empirical research on how citizens themselves define their responsabilities and 'good citizenship' is limited. By contrast, civic and political participation have been extensively studied, in Western Europe and - to a lesser extent - in Eastern Europe. In these studies, a wide range of theories have been applied to describe individual-level participation in politics and civil society. Less is known, however, about the applicability of these theories with respect to civic mindedness in Eastern Europe. In this paragraph, we briefly review relevant theories of political and civic participation, which relevance to explain citizenship norms will be tested in our empirical section.

To begin, a vast body of research supports religion as an explanation of political and civic behavior (Driskell et al. 2008; Hooghe 2003a; Park and Smith 2000; Putnam 2000; Verba et al. 1995). There has been consistent evidence of a positive relationship between both religious faith and church attendance and political and civic participation (Beyerlein and Chaves 2003; Billiet 1998; Hooghe 2003a; Wuthnow et al. 1990). Concerns about fundamentalist religion aside, most scholars have noted that most religious congregations and groups are contributing important resources that help sustain the vitality of civil society (Welch et al. 2004). Several reasons have been given for the positive relationship between religiosity and civic involvement (Crystal and DeBell 2002). First, religion tends to bring people into social networks and creates strong associational ties. It is related to Durkheim's (1912) argument that rituals of religion generate group cohesion and solidarity, intensifying the links between citizens and their society. Second, active involvement in a religious faith enhances general organizational knowledge and skills (Deleon and Naff 2004). In particular scholars of political sociology emphasize that religion provides an important source of social capital and democratic skills that facilitate democratic participation (Verba et al. 1995). Finally, faith may promote civic orientation indirectly because churches or synagogues are venues where issues of public concern are discussed or directly challenged through preaching and endorsing norms of cooperation and civic involvement.

Compared to the studies mentioned above which have been conducted in Western societies, research on Eastern Europe revealed less convincing relations between religion and citizens' participation. Letki (2004) did not find a significant effect of church-service attendance on political participation, and Badescu and Neller (2007) show that Eastern European countries display weaker relationships between church attendance and involvement in associations. Communist efforts to stamp out religion and to exclude religious organizations from public life may explain why such weaker correlations appear in Eastern than in Western Europe.

Myriad studies - both in Western and former communist countries-have pointed to differences between men and women in political participation, suggesting a so-called 'gender gap'. They report that women are less involved than men in political and social life, mostly due to their lack of socio-economic resources (Schlozman et al. 1995; Letki 2004). One such a resource is women's occupational status. Beckwith (1986) revealed that differences in occupational status account for gender differences in levels of political involvement. It is indeed a tacit assumption in most research that occupational status affects political participation (Verba et al. 1995). Another resource which is a commonly 
used factor to explain variations in political and social participation is education. It is consistently found that education increases participation (Hooghe 2003a; Wolfinger and Rosenstone 1980). Education offers people the necessary resources and skills to participate in political and social life. Besides, it may, as Denny and Doyle (2008: 294) note: "instil a sense of civic duty by fostering democratic values and beliefs and encouraging participation in socially orientated activities." It is also shown that marriage increases time spent in formal community organizations and neighborhood, and fosters political activity (Putnam 2000; Verba et al. 1997).

In the recent literature on participation, several authors have painted a portrait of declining participation levels and an unengaged younger generation. For example, Putnam (2000) has observed an erosion of civic community in the USA due to generational replacement. This lament about a lack of commitment to community within the younger generation has however been challenged by some analysts. They emphasize the development of a new style of citizenship. Dalton (2006b) shows that old forms of political participation are in a downward spiral and that younger people are less likely to vote and to participate in campaign activities. At the same time, Dalton (2006b) illustrates that citizeninitiated and policy-oriented forms of political activity gradually acquire importance, particularly among the younger generation. So, even though age increases traditional types of civic and political participation such as voting, young citizens are more active in less mainstream types of activism (Dalton 2006b). With respect to citizens' social participation in Eastern Europe, some scholars (Howard 2002) have stated that a generational shift might cause an increase of participation. Sztompka (1996: 126) argues that: "as long as the majority of the population consists of the people whose young, formative years, and therefore crucial socializing experiences fall under the rule of the communist regime, one can expect the continuing vitality of the bloc culture." However, he adds that this will change over time, as "new demographic cohorts replace the older generations at the central positions in a society." Nevertheless, empirical research has so far shown a positive and highly statistically significant impact of age on political involvement (Letki 2004).

Finally, the literature on social capital (Putnam 2000) links trust to civic community, participation and membership. The higher the institutional trust citizens have, the stronger their social and political involvement. A public that is dissatisfied with political institutions is less likely to vote and may be hesitant to serve on a jury or perform other public service activities (Dalton 2006b).

In addition to trust in institutions, social trust has been linked to citizen involvement. DiFrancesco and Gitelman (1984: 610) note that "trust is essential to cooperative public activity." Putnam (1995: 73) formulated a similar line of reasoning when stating that "social trust and civic engagement are strongly correlated." According to Putnam (1995), trust and involvement are two facets of social capital. In their recent cross-national comparison of the USA, Eastern and Western Europe, Howard and Gilbert (2008) find that active citizens are more likely to be trusting than inactive people. In her study on political involvement in ten East European countries, Letki (2004) notes that the impact of social trust is positive but weak. Gibson's (2001) analysis reveals that interpersonal trust has little to do with attitudes toward democratic institutions and processes. He suggests that while citizens of post-communist countries use networks and interpersonal trust in everyday life, these resources are politically largely irrelevant. Dekker et al. (1997) found that social trust is not related to membership or volunteering in certain types of groups such as political parties in most of the fourteen West European countries investigated by the authors. 


\section{Data and Measurement}

As noted above, in this paper we investigate citizens' own definitions of citizenship in Eastern Europe. Even though politicians expect citizens to be "responsible," the exact meaning of responsibility and good citizenship is open to multiple interpretations (Dalton 2006a), and citizens themselves might hold different definitions.

We employ data from the European Social Survey (ESS) large-scale comparative research project. The ESS is a cross-national collaboration of surveys, each of which is fielded by a scientific organization within the member nation, offering data representative for the countries' adult population (older than 15). ${ }^{1}$ The first round of the ESS in 2002 looked into the meaning of citizenship for citizens themselves, which makes it valuable for our study. We include in our analysis the four Eastern European countries with available data on citizenship norms: Slovenia, the Czech Republic, Hungary and Poland, resulting in 6,674 respondents. Before turning to the analyses, we will discuss the dependent and independent variables in the next two sections.

\subsection{Dependent Variables}

To investigate what citizens actually think about citizenship, the respondents were asked how they think a "good citizen" should behave: "To be a good citizen, how important is it for a person to...." The following items were listed (scored from 0 if considered extremely unimportant to 10 if considered extremely important):

- vote in elections

- be active in voluntary associations

- be active in politics

- support others who are worse off in society

- form an independent opinion

- obey laws and regulations

The ESS question thus considers different aspects of citizenship (Dalton 2006a). First, it defines citizenship in terms of attitudes toward the role of the individual in the political and social system, a role that is central to the literature on democracy. Then, the survey taps into the citizen's autonomy by asking about the importance of forming an independent opinion, and finally, it looks at the acceptance of state authority (i.e., obeying laws and regulations) as referring to social order. Solidarity as a category of citizenship is included through the question about a citizen's concern for others.

There is a pluralism of civic norms and citizens may have different images of a "good citizen". In line with Dalton's (2006a) research with regard to the American public, we operationalized two components: citizen duty and engaged citizenship. The first involves a norm of social order (i.e., the importance of obeying laws and regulations) and the responsibility to vote. It stresses obligations and refers to a more traditional concept of citizenship. The second includes measures of solidarity and voluntary engagement. According to Dalton (2006a), this expressive, participatory emphasis of engaged citizenship overlaps with the patterns of post-material or self-expressive values that Inglehart (1990) has related to post-industrial societies. Inglehart (1990) has pointed out that the

${ }^{1}$ Detailed information about the survey and the sampling procedures is available on the survey's website: http://www.europeansocialsurvey.org 
Table 1 Citizenship components

Source European Social Survey 2002

\begin{tabular}{lcc}
\hline & $\begin{array}{l}\text { Engaged } \\
\text { citizenship }\end{array}$ & Citizen duty \\
\hline Active in voluntary associations & 0.86 & \\
Active in politics & 0.81 & \\
Supporting people worse off & 0.67 & \\
Forming independent opinions & 0.57 & \\
Voting in elections & & 0.85 \\
Obeying laws and regulations & 2.15 & 0.85 \\
Eigenvalue: & 53.84 & 71.84 \\
Percentage variance: & 0.71 & 0.58 \\
Cronbach's alpha: & & \\
\hline
\end{tabular}

value change that accompanies modernisation provides the basis of a new, more participatory, type of social and political order and citizenship.

The results of operationalizing the two components using a principle component analysis (PCA) are summarized in Table 1.

The first dimension refers to the engaged type of citizenship norms. It primarily involves forms of participation. Participation in voluntary associations is most strongly related to this component (.86), closely followed by being active in politics (.81). The component also incorporates a measure of solidarity and a norm of autonomy (that one should form opinions independently of others). The second dimension, citizen duty, involves the responsibility to vote and to obey laws and regulations. ${ }^{2}$

\subsection{Explanatory Variables}

To begin, we consider two measurements of religion. Religious denomination is divided into a dummy which takes the value of 1 when the respondent considers him/herself to be religious and 0 otherwise. Religious attendance is a continuous variable ranging from 1 to 7 and coded such that higher scores represent more religious involvement.

Education represents a variable of three categories: respondents whose highest attained education level is primary, those whose highest level is secondary, and those who have had an education beyond secondary. Gender is a dummy variable with the value 0 for male and 1 for female respondents. Age, measured by the year of birth of respondents, is a continuous variable and of particular importance in a study of Eastern Europe, given the effect of socialization and the expectation of a generational change (Sztompka 1996). Finally, we have added marital and occupational status as dummy variables: marital status is equal to 1 for married respondents ( 0 otherwise) and occupational status is equal to 1 for the respondents who have performed paid work during the seven days before the survey $(0$ otherwise).

In addition to demographic variables, we also introduce two attitudinal variables: social and political trust. ${ }^{3}$ Both indicators of trust are constructed through a PCA using the

\footnotetext{
2 The internal consistency (measured by Cronbach's alpha) is relatively low with regard to the component of citizenship duty. This is obviously (partly) because of the short battery. Unfortunately, the ESS only includes the two-item solution to measure norms of citizenship duty.

${ }^{3}$ Note that the explanation of citizenship norms by trust may face problems of reverse causality. Indeed, one may argue that trust affects the creation of citizenship norms, but an alternative argument could be that
} 
responses on multiple related statements. Social trust pertains to trust in people. The scale includes agreement (ranging from 0 tot 10) that "most people can be trusted," "most people try to be fair," and "people mostly try to be helpful." This three-item scale of social trust allows for a more precise measurement of social or general trust than the use of a single item (Reeskens and Hooghe 2008). The component of trust in institutions spans trust in the following types of institutions: the legal system, parliament, politicians, the police and the United Nations. The possible answers for the five items for trust in institutions range from (0) "no trust at all" to (10) "complete trust."

Descriptive statistics for all variables in our analyses are provided in Table 2.

\section{Cross-National Differences in Citizenship Norms}

In addition to describing levels of our dependent and independent variables, Table 2 is useful to look at cross-national differences in citizenship norms. We find significant differences in both citizenship norms across our sample of four Eastern European countries. In Hungary, duty-based norms of citizenship, which stress obligations to the state and participation through elections, are omnipresent, but engaged citizenship is low. Hungarian citizens seem to define citizenship more in terms of duties and obligations than in terms of engagement and self-expression. The opposite is found for people in Slovenia, who hold an engaged image of citizenship rather than a duty-based one. The citizens of the Czech Republic are characterized by the lowest level of civic norms. Finally, Polish citizens score relatively high on both measures of civic mindedness.

These differences in citizenship norms across a range of Eastern European countries underline that the region of Eastern Europe cannot be considered as a monolithic entity. As discussed above, even though all countries in the region underwent a lengthy period of socialization to Soviet-style norms and behavior, and were characterized by similar state and party structures and economic and social mechanisms (McGregor 1996), there are broad contrasts between the countries. Our findings seem to confirm that citizens of the Czech Republic which had a strong egalitarian structure and rigid communism (Wallace 1997; Janos 1996), and where the leadership did not show any willingness to accept the movement toward democratic reform (Ishiyama 1995; Wolchik 1992) have the weakest norms of citizenship. In Poland, on the other hand, where the communist system had more difficulties to penetrate into society (Korbonski 1992), citizens appear to hold more civicoriented norms. Besides, Poland is the best-known example of a strong Catholic state, with the most crowded churches in Europe and a low level of religious fractionalization (Alesina et al. 2003), and evidence suggests that "religious legacies leave a distinct and lasting imprint on contemporary values" (Norris and Inglehart 2003: 7).

The emphasis of Slovenia's citizens on engaged citizenship norms may be linked to the civil tranquility and strong economic growth which have marked the period after the country's independence. United Nations (2002) figures also indicate that Slovenia

Footnote 3 continued

trust is fostered by norms of social citizenship. In studies of social capital, the claim of a connection between membership in voluntary associations and democracy is based on the assumption that membership in voluntary associations facilitates the effects of socialisation as well as democratic learning (Stolle 1998). Within voluntary associations or so-called schools of democracy, opinions, attitudes and ideas may indeed be formed. Yet, because we are looking at citizenship norms rather than behaviour, we believe that the problem of causality is less severe in our analysis. Having ideas about citizenship is less likely to influence trust than is social behaviour (such as participation in voluntary organizations). 


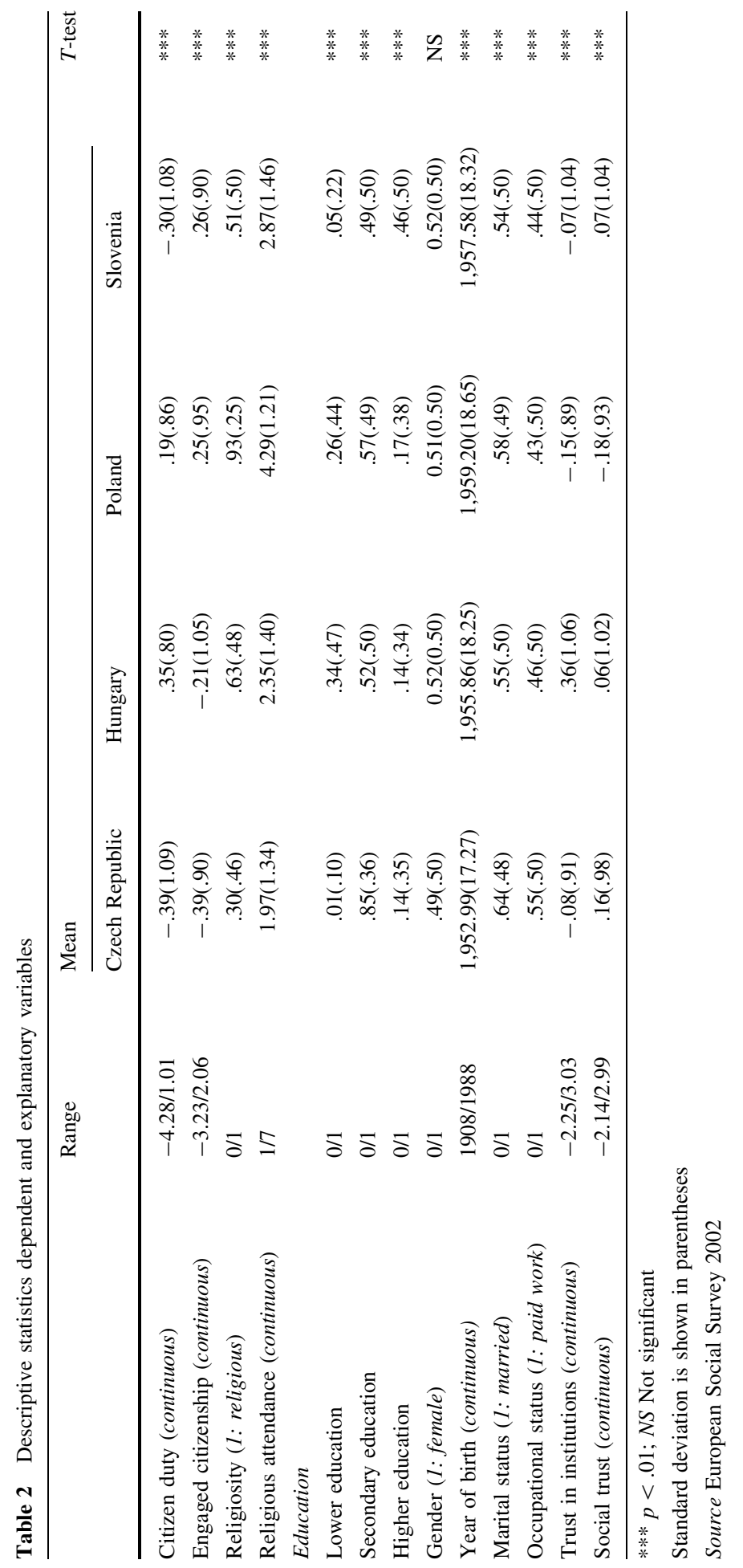


has-together with Poland-the highest level of education among the former Soviet countries. The link between these social characteristics and the norms of engaged citizenship among Slovenia's citizens corresponds with Dalton's (2006b) argument that a new style of citizen politics is developing as a result of the socioeconomic transformation of these countries. Dalton (2006b) states that the changes in Western societies, which have led to a new form of post-industrial society over the past five decades, have resulted in a new pattern of political thought and action. Rather than stressing the citizen's obligations to the state and participation through elections, this new idea of citizenship emphasizes selfexpressive and self-actualizing values. That Slovenians are less respectful of authority and less likely to define citizenship in duty-based terms may thus be linked to the more postindustrial structure of the country. Indeed, Dyson (2007) argues that Slovenia's economic structure is closer to the West-European (Euro Area) states than it is to other Eastern European states.

Even though these explanations of cross-national differences are tentative, our findings seem to support the influence of the peculiarities of the countries' political and historical context on citizens' civic mindedness.

\section{Explanatory Multivariate Analysis}

In order to test the influence of the different explanatory variables presented above on citizenship norms, we performed separate regression analyses for each dependent variable and for the four countries separately (see Table 3). In doing this, we not only investigate the explanatory value of the different variables, but also explore whether significant differences appeared across the Eastern European countries included in our study.

Let us start the discussion of the results with the variable of religion. The effect of religiosity on citizenship norms is limited. We only find the magnitude and positive influence of religion on participation typical in Western Europe in Poland with respect to civic norms. Of course, nowhere in Eastern Europe but Poland, the church was so closely connected with anti-communist resistance and so effective in resisting the communist regime (Schanda 2003; Stark 2001). However, whereas religiosity is significantly related to citizenship norms in Poland, church attendance does not influence Polish people's civic mindedness. In the other countries by contrast, the effect of church attendance is-with the exception of citizen duty in the Czech Republic-significant. Differences thus occur between the four Eastern European countries in our sample. In contrast to previous participation research that revealed low influence of church attendance in Eastern Europe, it seems a relevant predictor for citizenship norms in Slovenia, Hungary and the Czech Republic. Church attendance positively affects norms of duty-based citizenship in Hungary and Slovenia and engaged citizenship in the three countries, underscoring Durkheim's (1912) claim about the effect of participation in rituals on solidarity and morality.

In the Czech Republic, the educational level does not significantly influence citizenship norms. Education also seems irrelevant when explaining individual differences in norms of engaged citizenship in Poland and norms of citizens' duty in Slovenia. In Hungary and in Poland-with respect to citizenship duty norms - education has the effect on citizenship norms that is generally observed in the literature on civic participation (Coffé and Geys 2007; Dalton 2006b; Hooghe 2003a): higher education propels civic mindedness. In Slovenia, the respondents with a secondary level of education distinguish themselves from the lower and higher educated with their high level of civic mindedness. So once again, differences between countries occur. 


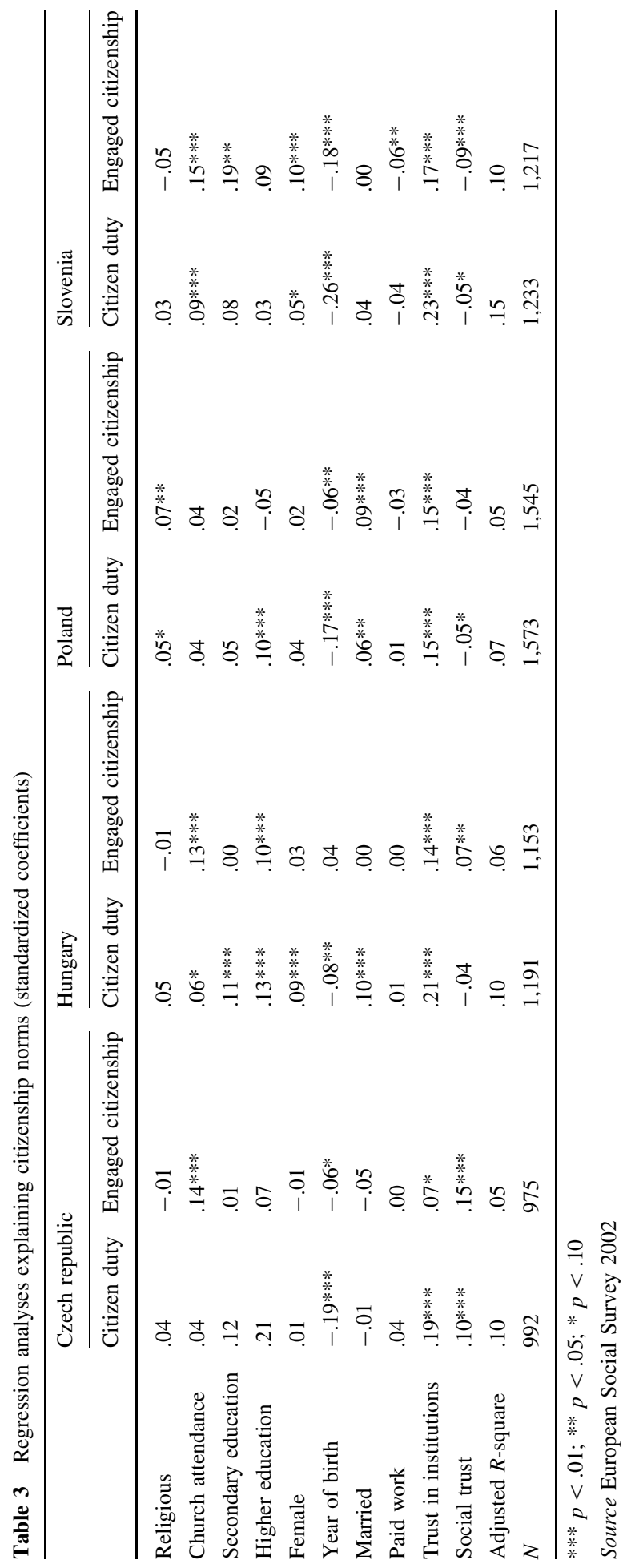


In contrast to the so-called gender gap with respect to political and civic participation (Hooghe 2003a; Verba et al. 1997), gender differences in citizenship norms in Eastern Europe seem limited. Besides, in those cases where differences occur (i.c. norms of citizen duty in Hungary and both engaged and duty-based citizenship in Slovenia), women hold stronger norms of good citizenship, supporting previous claims about women's more social attitudes and more law-abiding behavior (Hooghe 2003b; Steffensmeier and Allan 1996; Tyler 2006).

As far as age is concerned, we find that younger respondents have significantly fewer norms of duty-based citizenship than do older respondents. This corresponds with participation research (Putnam 2000) and Dalton's (2006a, 2008b) conclusion with respect to Americans' citizenship norms. Dalton (2006a, 2008b) noticed that the post-war baby-boom generation and Americans who came of age at the end of World War II scored highest on citizenship duty. They define citizenship in terms of duties and obligations. At the same time, he found that "the erosion of duty-based norms is counterbalanced by somewhat greater support for norms of engaged citizenship among younger cohorts" (Dalton 2006a: 10). Dalton (2008b: 39) believes that the young reflect a more deliberative image of citizenship. Our results for engaged citizenship norms in Eastern European countries do not find a similar generational shift in citizenship norms. Year of birth is not significantly correlated with engaged citizenship in Hungary, but it is significantly but negatively related to engaged citizenship in Slovenia, Poland and-weakly-in the Czech Republic. This contradicts the argument stated in previous research (Howard 2002) on civil society in post-communist Europe that a generational shift might result in an increase in organizational membership and participation.

Being married has a positive influence on the orientation of Polish citizens toward both components of citizenship and also has a significant and positive effect on the formation of norms of citizen duty in Hungary. This finding is in line with Putnam's (1996) argument that single people — both men and women, divorced, separated and never married-are significantly less engaged civically than married people. Yet, it is only a relevant predictor in three of our eight models, again underlying cross-national differences in the explanatory power of variables.

The influence of occupational status on citizenship norms is limited. It is only a relevant catalyst for engaged norms of citizenship in Slovenia: Slovenian citizens who have paid work display fewer norms of engaged citizenship.

Turning to the attitudinal explanatory variables, we find that there is a statistically significant relationship between trust in institutions and both components of citizenship norms in all four countries. With the exception of engaged citizenship in the Czech Republic, the relationship is significant at the 0.01 level of significance. The results are more mixed with regard to social trust. The influence of social trust on citizenship norms is highly significant and positive in the Czech Republic. In Hungary, social trust is significantly and positively correlated only with the norms of engaged citizenship. In Poland, on the other hand, social trust is only significantly, but weakly, related to the more traditional type of citizenship. Moreover, in contrast to previous research on participation, the relationship is negative in Poland: the higher the level of social trust, the lower the norms of citizen duty. A similar negative relationship is found in Slovenia, for both norms of engaged citizenship and citizenship duty. Hence, the variable of social trust that is traditionally associated positively with civic participation (Putnam 1995) performs differently for citizenship norms in Slovenia and Poland.

In general, vertical trust seems to provide a better explanation of citizenship norms than horizontal or social trust. This appears to validate the findings of Letki (2004) in Eastern 
Europe and Dekker et al. (1997) in Western Europe that people do not base democratic citizenship on the basis of whether they believe people can be trusted. Our findings reveal that people seem to need to trust their national institutions in order to hold participatory citizenship norms.

Before turning to our conclusion and discussion, it is important to note that the explained variance of the models is relatively low. It was only possible to explain more than 10 per cent of the variance for the duty type of citizenship norms in three countries (the Czech Republic, Hungary and Slovenia). The explained variance for the engaged type of citizenship varies between 5 per cent (Poland) and 10 per cent (Slovenia). The fact that the explained variance is generally lower for the concept of engaged citizenship might indicate that this more expressive and participatory type of citizenship is more difficult to explain via socio-economic characteristics which have traditionally been related to conventional types of political and civic participation, at least in those Eastern European countries included in our study. It should also be noted that the explained variance in previous research on civic participation in general (Badescu and Neller 2007; Hooghe 2003a) and norms of good citizenship in particular (Denters et al. 2007) has generally been relatively low. Besides, comparative research on civic and political participation including both Western and Eastern European countries consistently found lower levels of explained variance for the Eastern European countries (Armingeon 2007; Badescu and Neller 2007). It shows that theories and models developed in Western societies cannot simply be exported to recently developed democracies.

\section{Conclusion and Discussion}

Compared to citizens from Western Europe, Eastern European citizens show lower levels of civic and political engagement; a gap which has been ascribed to the domination of communism within that Eastern European region for several decades. Due to the legacy of communism, there are also grounds to expect weak citizenship norms. Citizens need to (re)learn civic and political attitudes and behavior, and previous research has indeed shown a low level of citizen participation in civil society and politics in Eastern Europe (Geremek 1992; Howard 2002; Lomax 1997; Smolar 1996). It is surprising that no previous largescale empirical analysis has-to the best of our knowledge-considered citizens' own definition of citizenship or civic mindedness in these newly established democracies, because citizens' own definitions of citizenship could help to get a fuller understanding of political and civic behavior. Therefore, in this paper, we have considered how citizens themselves define "good citizenship" in four Eastern European countries (the Czech Republic, Hungary, Poland and Slovenia). In particular, we have studied duty-based and engaged norms of citizenship, as defined by Dalton (2006a, 2008a, b). Whereas the first stresses citizen obligations to the state and participation through elections, the second refers to social engagement and social concern. We have compared the presence of both citizenship norms in the Eastern European countries included in our study and developed a model of citizenship norms based in previous research on civic and political participation.

Significant differences in the level of civic mindedness between the different countries occur. Citizens of the Czech Republic score lowest on both types of citizenship norms. Polish citizens have an image of citizenship that is both strongly engaged and duty-based. Hungarian citizens seem to hold a traditional view regarding citizenship, focussing on the need to participate in elections and obey laws. Slovenian citizens, on the other hand, have a more modern definition of citizenship and define it more in terms of engagement. These 
findings seem to support the view that the communist experience and the penetration of communism within society still influences citizens' views on citizenship, thus supporting the cultural theories that emphasize the macro-context within which political learning and the development of political norms and attitudes occur (Mishler and Rose 2002).

Moving onto our explanatory models for citizenship norms, our results fit nicely with some established claims on civic and political participation (mostly from studies on Western democracies): older people and people with high levels of trust in institutions show more civic mindedness. For other variables however, our findings contradict previous participation research and-what is probably more intriguing — show contradictory findings between different countries. To give one example, whereas social trust is significantly and positively related to citizenship norms in the Czech Republic and Hungary (with the exception of citizen duty where there is no significant effect), it is significantly and negatively related to civic mindedness in Poland and Slovenia.

This cross-national variation, both in level of civic mindedness and in the relationships between some individual explanatory variables and citizenship norms, highlight that Eastern Europe cannot be considered as a monolithic and homogeneous bloc. While all countries in the region underwent a lengthy period of socialization to Soviet-style norms and behavior, and were characterized by similar state and party structures and economic and social mechanisms (McGregor 1996), there are broad contrasts between the countries. These differences among communist regimes in Eastern Europe and the penetration of communism in the different societies may explain the differences in citizenship norms. Future research should investigate this tentative explanation in greater detail and further investigate the relevance of the peculiarities of the countries' political and historical context.

We believe that this assessment of citizenship norms in Eastern European countries provides an interesting complement to previous research on civil society and political and civic participation. Dalton (2008a) has indeed argued that an understanding of citizens' ideas of citizenship is needed to gain a more complete understanding of their political and civic behavior. Yet, Marquart-Pyatt and Paxton (2007: 104) note that, "the greater institutional uncertainty in Eastern Europe may cause citizens to be unwilling to translate democratic values in practice." Hence, a next interesting step would be a comprehensive study on the link between citizenship norms and political and civic behavior.

Acknowledgments The authors wish to thank Catherine Bolzendahl, Karien Dekker and Jerzy Wiatr for their valuable comments and suggestions.

Open Access This article is distributed under the terms of the Creative Commons Attribution Noncommercial License which permits any noncommercial use, distribution, and reproduction in any medium, provided the original author(s) and source are credited.

\section{References}

Adam, F., Makarovič, M., Rončević, B., \& Tomšič, M. (2004). The challenges of sustained development: The role of socio-cultural factors in East Central Europe. Budapest and New York: Central European University Press.

Alesina, A., Devleeschauwer, A., Easterly, W., Kurlat, S., \& Wacziarg, R. (2003). Fractionalization. Journal of Economic Growth, 8, 155-194. doi:10.1023/A:1024471506938.

Almond, G., \& Verba, S. (1963). The civic culture. Princeton: Princeton University Press. 
Armingeon, K. (2007). Political participation and associational involvement. In J. W. van Deth, José. Ramón. Montero, \& Anders. Westholm (Eds.), Citizenship and involvement in European democracies. A comparative analysis (pp. 358-383). Oxon: Routledge.

Badescu, G., \& Neller, K. (2007). Explaining associational involvement. In J. W. van Deth, J. R. Montero, \& Anders. Westholm (Eds.), Citizenship and involvement in European democracies. A comparative analysis (pp. 158-187). Oxon: Routledge.

Bakuniak, G., \& Nowak, K. (1987). "The creation of a collective identity in a social movement: The case of "Solideranośćc" in Poland. Theory and Society, 16, 401-429. doi:10.1007/BF00139488.

Beckwith, K. (1986). American women and political participation: The impacts of work, generation, and feminism. Westport, CT: Greenwood.

Beyerlein, K., \& Chaves, M. (2003). The political activities of religious congregation in the United States. Journal for the Study of Religion, 42(2), 229-246. doi:10.1111/1468-5906.00175.

Billiet, J. (1998). Social capital, religious-philosophical involvement and social integration in Belgium: An empirical investigation. In Rudi. Laermans, Bryan. Wilson, \& Jaak. Billiet (Eds.), Secularization and social integration (pp. 233-250). Leuven: Leuven University Press.

Coffé, H., \& Geys, B. (2007). Participation in bridging and bonding associations and civic attitudes. VOLUNTAS: International Journal of Voluntary and Nonprofit Organizations, 18(4), 385-406. doi: 10.1007/s11266-007-9048-2.

Colton, T. J. (2000). Transitional citizens: Voters and what influences them in the New Russia. Cambridge, MA: Harvard University Press.

Conover, P. J., Crewe, I. M., \& Searing, D. D. (1991). The nature of citizenship in the United States and Great Britain: Empirical comments on theoretical themes. The Journal of Politics, 53(3), 800-832. doi: $10.2307 / 2131580$.

Conover, P. J., Searing, D. D., \& Crewe, I. M. (2004). The elusive ideal of equal citizenship: Political theory and political psychology in the United and Great Britain. The Journal of Politics, 66(4), 1036-1068. doi:10.1111/j.1468-2508.2004.00289.x.

Crystal, D. S., \& DeBell, M. (2002). Sources of civic orientation among American youth: Trust, religious valuation, and attributions of responsibility. Political Psychology, 23(1), 113-132. doi: 10.1111/0162-895X.00273.

Curtis, J. E., Baer, D. E., \& Grabb, E. G. (2001). Nations of joiners: Explaining voluntary association membership in democratic societies. American Sociological Review, 66, 783-805. doi:10.2307/ 3088873.

Dalton, R. J. (2006a). "Citizenship norms and political participation in America: The good news is... the bad news is wrong”. CDACS occasional paper 2006-01. Washington DC: The Center for Democracy and Civil Society, Georgetown University.

Dalton, R. J. (2006b). Citizen politics. Public opinion and political parties in advanced industrial democracies. Washington DC: CQ Press.

Dalton, R. J. (2008a). Citizenship norms and the expansion of political participation. Political Studies, 56, 76-98. doi:10.1111/j.1467-9248.2007.00718.x.

Dalton, R. J. (2008b). The good citizen. How a younger generation is reshaping American politics. Washington DC: CQ Press.

Dekker, P., Koopmans, R., \& van den Broek, A. (1997). Voluntary associations, social movements and individual political behaviour in Western Europe. In J. W. van Deth (Ed.), Private groups and public life. Social participation, voluntary associations and political involvement in representative democracies (pp. 220-241). London: Routledge.

Deleon, R. E., \& Naff, K. C. (2004). Identity politics and local political culture: Some comparative results from the social capital benchmark survey. Urban Affairs Review, 39(6), 689-719. doi: $10.1177 / 1078087404264215$.

Denny, K., \& Doyle, O. (2008). Political interest, cognitive ability and personality: Determinants of voter turnout in Britain. British Journal of Political Science, 38, 291-310. doi:10.1017/S000712340800015X.

Denters, B., Gabriel, O., \& Torcal, M. (2007). Norms of good citizenship. In J. W. van Deth, José. Ramón. Montero, \& Anders. Westholm (Eds.), Citizenship and involvement in European democracies. A comparative analysis (pp. 88-108). Oxon: Routledge.

Deth, V. J. (2007). Norms of citizenship. In Russell. J. Dalton \& Hans.-Dieter. Klingemann (Eds.), The oxford handbook of political behaviour (pp. 402-417). Oxford: Oxford University Press.

DiFrancesco, W., \& Gitelman, Z. (1984). Soviet political culture and 'covert participation' in policy implementation. The American Political Science Review, 78, 603-621. doi:10.2307/1961832.

Driskell, R., Embry, E., \& Lyon, L. (2008). Faith and politics: The influence of religious beliefs on political participation. Social Science Quarterly, 89(2), 294-314. doi:10.1111/j.1540-6237.2008.00533.x. 
Durkheim, E. (1912). Les formes élémentaires de la vie religieuse. Le système totémique en Australie. Paris: Les Presses Universitaires de France.

Dyson, K. (2007). Euro area entry in East-Central Europe: Paradoxical Europeanisation and clustered convergence. West European Politics, 30(3), 417-442. doi:10.1080/01402380701276279.

Fidrmuc, J., \& Gërxhani, K. (2005). "Formation of social capital in central and eastern Europe: Understanding the gap vis-à-vis developed countries”. CEPR discussion paper no. 5068. London: Centre of Economic Policy Research.

Geremek, B. (1992). Problems of post-communism: Civil society then and now. Journal of Democracy, 3, $3-12$.

Gibson, J. L. (2001). Social networks, civil society, and the prospects for consolidating Russia's democratic transition. American Journal of Political Science, 45(1), 51-69. doi:10.2307/2669359.

Grzymala-Busse, A. (2002). The programmatic turnaround of communist successor parties in East Central Europe, 1989-1998. Communist and Post-Communist Studies, 35, 51-66. doi: 10.1016/S0967-067X(01)00024-1.

Hooghe, M. (2003a). Why should we be bowling alone? Results from a Belgian survey on civic participation. VOLUNTAS: International Journal of Voluntary and Nonprofit Organizations, 14(1), 41-59. doi:10.1023/A:1022940921725.

Hooghe, M. (2003b). Participation in voluntary associations and value indicators: The effect of current and previous participation experiences. Nonprofit and Voluntary Sector Quarterly, 32, 47-69. doi: $10.1177 / 0899764003251198$.

Howard, M. M. (2002). The weakness of postcommunist civil society. Journal of Democracy, 13(1), 157169. doi:10.1353/jod.2002.0008.

Howard, M. M., \& Gilbert, L. (2008). A cross-national comparison of the internal effects of participation in voluntary organizations. Political Studies, 56(1), 12-32. doi:10.1111/j.1467-9248.2007.00715.x.

Hutcheson, D. S., \& Korosteleva, E. A. (2006). Patterns of participation in post-Soviet politics. Comparative European Politics, 4, 23-46. doi:10.1057/palgrave.cep.6110068.

Inglehart, R. (1990). Culture shift in advanced industrial society. Princeton: Princeton University Press.

Inglehart, R., \& Catterberg, G. (2002). Trends in political action: The developmental trend and the posthoneymoon decline. International Journal of Comparative Sociology, 43(3-5), 300-316. doi: $10.1177 / 002071520204300305$.

Ishiyama, J. T. (1995). Communist parties in transition: Structures, leaders and processes of democratization in Eastern Europe. Comparative Politics, 27(2), 147-166. doi:10.2307/422162.

Janos, A. C. (1996). What was communism? A retrospective in comparative analysis. Communist and PostCommunist Studies, 29(1), 1-24. doi:10.1016/S0967-067X(96)80009-2.

Korbonski, A. (1992). Poland: 1918-1990. In Joseph. Held (Ed.), The Columbia history of Eastern Europe in the twentieth century (pp. 229-276). New York: Columbia University Press.

Letki, N. (2004). Socialization for participation? Trust, membership, and democratization in east-central Europe. Political Research Quarterly, 57(4), 665-679.

Lomax, B. (1997). The strange death of civil society in post-communist Hungary. Journal of Communist Studies and Transition Politics, 13, 41-63. doi:10.1080/13523279708415331.

Markowski, R. (1997). Political parties and ideological spaces in east central Europe. Communist and PostCommunist Studies, 30(3), 221-254. doi:10.1016/S0967-067X(97)00006-8.

Marquart-Pyatt, S., \& Paxton, P. (2007). In principle and in practice: Learning political tolerance in Eastern and Western Europe. Political Behavior, 29, 89-113. doi:10.1007/s11109-006-9017-2.

McGregor, J. P. (1996). Constitutional factors in politics in post-communist central and Eastern Europe. Communist and Post-Communist Studies, 29(2), 147-166. doi:10.1016/S0967-067X(96)80003-1.

Mishler, W., \& Rose, R. (2002). Learning and re-learning regime support: The dynamics of post-communist regimes. European Journal of Political Research, 41, 5-36. doi:10.1111/1475-6765.00002.

Need, A., \& Evans, G. (2001). Analysing patterns of religious participation in post-communist Eastern Europe. The British Journal of Sociology, 52(2), 229-248. doi:10.1080/00071310120044962.

Norris, P., \& Inglehart, R. (2003). Islamic culture and democracy. Testing the "Clash of Civilizations". In Ronald. Inglehart (Ed.), Human values and social changes. Leiden, Boston: Brill.

Paldam, M., \& Svedsen, G. T. (2000). An essay on social capital: Looking for the fire behind the smoke. European Journal of Political Economy, 16(2), 339-366. doi:10.1016/S0176-2680(99)00064-6.

Park, J. Z., \& Smith, C. (2000). "To whom much has been given...": Religious capital and community voluntarism among churchgoing protestants. Journal for the Scientific Study of Religion, 39(3), 272286. doi:10.1111/0021-8294.00023.

Putnam, R. D. (1995). Bowling alone: America's declining social capital. Journal of Democracy, 6(1), 6578. doi:10.1353/jod.1995.0002.

Putnam, R. D. (1996). The strange disappearance of civic America. The American Prospect, 13(7), 34-48. 
Putnam, R. D. (2000). Bowling alone. The collapse and revival of American community. New York: Simon \& Schuster.

Raciborski, Jacek., \& Wiatr, Jerzy. J. (2005). Demokratie in Polen. Elemente des politischen Systems. Opladen: Barbara Budrich.

Reeskens, T., \& Hooghe, M. (2008). Cross-cultural measurement equivalence of generalized trust. Evidence from the European social survey (2002 and 2004). Social Indicators Research, 85(3), 515-532. doi: $10.1007 / \mathrm{s} 11205-007-9100-\mathrm{z}$.

Rose, R., \& Makkai, T. (1995). Consensus or dissensus about welfare in post-communist societies? European Journal of Political Research, 28, 203-224. doi:10.1111/j.1475-6765.1995.tb00810.x.

Rose, R., Mishler, W., \& Haerpfer, C. (1998). Democracy and its alternatives: Understanding post-communist societies. Baltimore: Johns Hopkins University Press.

Rose-Ackerman, S. (2001). Trust and honesty in post-socialist countries. Kyklos, 54(2/3), 415-444.

Schanda, B. (2003). Religion and state in the candidate countries to the European Union-Issues concerning religion and state in Hungary. Sociology of Religion, 64(3), 333-348. doi:10.2307/3712488.

Schlozman, K. L., Burns, N., Verba, S., \& Donahue, J. (1995). Gender and citizen participation: Is there a different voice? American Journal of Political Science, 39, 267-293. doi:10.2307/2111613.

Schwartz, S. H., \& Bardi, A. (1997). Influences of adaptation to communist rule on value priorities in Eastern Europe. Political Psychology, 18(2), 385-410. doi:10.1111/0162-895X.00062.

Smolar, A. (1996). Civil society after communism: From opposition to atomization. Journal of Democracy, 7, 24-38. doi:10.1353/jod.1996.0018.

Stark, R. (2001). God, rituals, and the moral order. Journal for the Scientific Study of Religion, 40(4), 619636. doi:10.1111/0021-8294.00081.

Steffensmeier, D., \& Allan, E. (1996). Gender and crime: Toward a gendered theory of female offending. Annual Review of Sociology, 22, 459-487. doi:10.1146/annurev.soc.22.1.459.

Stolle, D. (1998). Bowling together, bowling alone: The development of generalized trust in voluntary associations. Political Psychology, 19(3), 497-525. doi:10.1111/0162-895X.00115.

Sztompka, P. (1996). Looking back: The year 1989 as a cultural and civilizational break. Communist and Post-Communist Studies, 29(2), 115-129. doi:10.1016/S0967-067X(96)80001-8.

Theiss-Morse, E. (1993). Conceptualizations of good citizenship and political participation. Political Behavior, 15(4), 355-380. doi:10.1007/BF00992103.

Tilly, C. (1984). Big structures, large processes, huge comparisons. New York: Russell Sage Foundation.

Tomka, M. (1998). Coping with persecution: Religious change in communism and in post-communist reconstruction in central Europe. International Sociology, 13(2), 229-248. doi:10.1177/02685 8098013002006.

Tyler, T. R. (2006). Why people obey the law. Princeton: Princeton University Press.

Verba, S., Burns, N., \& Schlozman, K. L. (1997). Knowing and caring about politics: Gender and political engagement. The Journal of Politics, 59(4), 1051-1072. doi:10.2307/2998592.

Verba, S., Schlozman, K. L., \& Brady, H. E. (1995). Voice and equality: Civic voluntarism in American politics. Cambridge, MA: Harvard University Press.

Völgyes, I. (1992). By way of a conclusion: Controlled and uncontrolled change in Eastern Europe. In Joseph. Held (Ed.), The Columbia history of Eastern Europe in the twentieth century (pp. 394-403). New York: Columbia University Press.

Völker, B., \& Flap, H. (2001). Weak ties as a liability: The case of East Germany. Rationality and Society, 13(4), 397-428. doi:10.1177/104346301013004001.

Wallace, C. (1997). "Who is for capitalism, who is for communism? Attitudes towards economic change in post-communist Eastern Europe: A 10 nation comparison”. East European series no. 44. Vienna: Institute for Advanced Studies.

Welch, M. R., Sikkink, D., Sartain, E., \& Bond, C. (2004). Trust in God and trust in man: The ambivalent role of religion in shaping dimensions of social trust. Journal for the Scientific Study of Religion, 43(3), 317-343. doi:10.1111/j.1468-5906.2004.00238.x.

Wiatr, J. J. (2003). Polish local elites and democratic change, 1990-2002. Communist and Post-Communist Studies, 36, 373-383. doi:10.1016/S0967-067X(03)00044-8.

Wolchik, S. L. (1992). Czechoslovakia. In Joseph. Held (Ed.), The Columbia history of Eastern Europe in the twentieth century (pp. 119-163). New York: Columbia University Press.

Wolfinger, R. E., \& Rosenstone, S. J. (1980). Who votes?. New Haven, CT: Yale University Press.

Wright, S., Kopač, A., \& Slater, G. (2004). Continuities within paradigmatic change. Activation, social policies and citizenship in the context of welfare reform in Slovenia and the UK. European Societies, 6(4), 511-534. doi:10.1080/1461669042000275881.

Wuthnow, R., Hodgkinson, V., et al. (1990). Faith and philantrophy in America. San Francisco: JosseyBass. 